\title{
Internationalization and Firm Performance: Case of Manufacturing Enterprises in Ecuador
}

\author{
Phan Anh Tu${ }^{1} \&$ Huynh Tuan Anh ${ }^{1}$ \\ ${ }^{1}$ School of Economics, Can Tho University, Vietnam \\ Correspondence: Phan Anh Tu, School of Economics, Can Tho University, Vietnam. E-mail: patu@ ctu.edu.vn
}

Received: August 6, 2020

Accepted: October 19, 2020

Online Published: January 3, 2021

doi:10.5430/rwe.v12n1p11

URL: https://doi.org/10.5430/rwe.v12n1p11

\begin{abstract}
This paper aims to investigate the impact of internationalization on manufacturing enterprise performance in Ecuador. Using a panel data of 90 enterprises in Ecuador over the year 2003, 2006, 2010, and 2017 collected by the Worldbank Enterprises Survey project, with the Random Effects Model (REM) and the Fixed Effects Model (FEM), the regression result shows that the degree of internationalization (DOI) has a non-linear impact on firm performance under the inverse S-shaped curve. Besides that, the factors related to the business environment, such as bribery, access to finance, and skilled laborers' barriers, also negatively impact these firms' performance. The study's implication provides not only for firms but also for policymakers to support Ecuador businesses in the process of internationalization.
\end{abstract}

Keywords: internationalization, performance, firm, inverted S-shaped curve, Ecuador

\section{Introduction}

The world is becoming flattered. The business has grown globalized to the present day, beyond a country's borders, leading firms to seek and expand into the international market, even if proactive or passive (Gankema et al., 2000). Therefore, internationalization is becoming a common trend in businesses' development goals (and economies globally). However, although empirical studies on the relationship between internationalization and performance have mushroomed in the developed countries, these efforts show the limitation of understanding both evidence of mixed or contradictory findings. Internationalization is a complex process and has many impacts on firm performance. The relationship between internationalization and firm performance has been a topic of intense research and debate for more than four decades. There have been many conclusions surrounding this relationship, but so far, there is no explicit agreement (Contractor et al., 2007).

Most empirical studies find a positive relationship between internationalization and firm performance (Zahra et al., 2000). The others have found negative or even non-linear relationships (Michel \& Shaked, 1986; Contractor et al., 2007). More importantly, few studies show little knowledge about this relationship in emerging-economies firms (Xiao et al., 2013). Many emerging-economy firms are recognized by quick adaptability and innovation but lack experience, knowledge and relatively young in the global competitive landscape. It opens a new window for scholars to understand better both theoretical and empirical perspectives of the internationalization-performance non-linear relationship consequences of emerging-economy firms. The context research of the emerging-economy firms like Ecuador is interesting because the traits of the macro-environment in emerging economies may change quickly compared with developed countries, and restrain or stimulate strategic actions, especially in emerging countries, which is a consequence of the interaction between organizational condition and domestic macro environment (Peng et al., 2009).

With the orientation to limiting trade vulnerability due to its economic dependence on the oil industry, the Ecuadorian government has focused on developing and "standardizing" the non-oil sector in Ecuador (food processing, textiles, automobile manufacturing, etc.) with the desire to bring Ecuador into a regional manufacturing center. However, in Ecuador, manufacturing businesses find it difficult to further increase internationalization by expanding into new markets outside the region. Because the Ecuadorian economy has long been highly dependent on oil, it began to focus on manufacturing in the 1960s; expanding into a new market with a longer distance will make businesses face many difficulties. Therefore, manufacturing firms may conduct their international expansion strategy may vary with their performance. 
Therefore, this study investigates the relationship between the degree of internationalization and firm performance and, consequently, whether or not firm performance may differ depending on the stages of the internationalization process under the S-shape. By using FEM and REM model to test this relationship, this current study's new contribution is to (a) find an inverse S-shape curve between DOI and manufacturing firm's performance, which is against the proposed new three-stage theory of international expansion by Contractor et al. (2003)' emphasis on firm performance in the service sector, (b) test this theory using data from 90 manufacturing firms over the year 2003, 2006, 2010, and 2017 in Ecuador, (c) shed new light on the growth of manufacturing firms by addressing differences among different barriers of the business environment in emerging economies, and (d) suggest that while prior studies have been descriptive, mainly depending on cross-sectional data, or using longitudinal data a panel data at the firm level used in this current study is scarce (Wang et al., 2020). Our empirical findings finally support the inverse S-shaped relationship between internationalization and firm performance.

This paper is structured as follows. In the next section, we present the literature review, and the hypothesis is suggested. Section 3 describes data and model specifications. The fourth section sets out the results and the discussions. The conclusion is the final section.

\section{Theoretical Foundation and Hypothesis Development}

\subsection{International Expansion and Firm Performance}

Over the last decades, studies on business firms' internationalization strategies have mushroomed (Luo and Zheng 2018). International expansion may help firms reap benefits from the global business environment, thereby enhancing their performance. Following this research stream, although internationalization definition is not widely accepted yet, this concept generally implies innovative and value-adding activities across national borders or the firms' outward movement (McDougall and Oviatt 2000). More importantly, internationalization strategy can be considered a useful tool for firms, especially for firms in emerging economies, to explore global business opportunities, thereby improving their financial performance.

Different theoretical-and-empirical perspectives of the relationship between internationalization and business performance of enterprises have been addressed. The positive link between international expansion and performance has been largely confirmed in most prior studies. For example, Pangarkar (2008) finds a positive association between internationalization and firm performance. According to several theories such as monopolistic advantage theory, internalization advantage theory, transaction cost theory, and eclectic paradigm theory, the international expansion of a firm or the degree of multinationality of Multinational enterprises (MNEs) has a positive relationship with the performance of the firm. MNEs may achieve a greater gradual learning process or a greater international experience to access the local strategic assets to obtain cheaper foreign resources (Contractor et al., 2003).

In contrast, Zaheer and Mosakowski (1997) have affirmed that internationalization has a negative linear relationship with firm performance. Because firms may initially endure foreignness liability, such as the costs of establishing its legitimacy abroad, the prices of acquiring foreign market knowledge, similar to these results, Wang et al. (2011) confirmed an inverted U-shaped relationship in which firms may enhance their performance by geographic expansion up to a 'threshold,' but its' returns will deteriorate as they may endure costs and complexity associated with further international expansion. Following contradictory results, Lu and Beamish (2001), Ruigrok et al. (2007) find evidence that the non-linear relationship between internationalization and performance may exist. It is because firms must burden the cost of new entrants at the early stage of internationalization. However, they may reap international expansion benefits to foster performance in the second stage because of international experiences. In other words, Benito-Osorio et al. (2016) concluded that the relationship between internationalization and firm performance follows a horizontal-S curve within large firms. In contrast, it shows a U-shaped for firms' medium size and linear negative for firms' small size.

Hence, the existing literature contradicts linear, U-shaped, inverted U-shaped relationships (Contractor et al., 2003). However, it is still unclear whether or not internationalization barriers at the first stage may be problematic for firm performance in different firms in various industry sectors (Xiao et al., 2013). Also, Kumar and Singh (2008) claimed that internationalized profit depends mostly on its internationalization stage.

In line with the arguments of a 'new' three-stage theory of the international expansion of Contractor et al. (2003), our current study argues that the non-linear relationship between internationalization and business performance by the S-shape, whereby the internationalization process has impacted on business performance in three stages: phase 1 shows the barriers that negatively affect business performance when participating in internationalization (Johanson and Vahlne, 1977). The reason is that early internationalizers have experienced enormous learning costs, the liability of 
foreignness, and insufficient economies of scale because of unfamiliarity with foreign markets, cultures and environments. Phase 2 is to explore the benefits of internationalization (Hutchinson et al., 2007). The reason is market-seeking, and resource-seeking firms may reap the incremental benefits of international expansion, outweigh the incremental costs such as access to lower-cost resources, achieve economies of scale and scope, obtain internalization of transaction costs, and extend product life cycles. However, Phase 3 negatively affects when international expansion exceeds an optimal threshold (Assaf et al., 2012). It means that further international development benefits are indefinitely positive due to the increased incremental costs of further expansion, the complexity of the global operation, and the cultural distance differences. Hence, it is detrimental to overall performance.

Hypothesis $\mathrm{H}_{1}$ : The degree of internationalization has a "non-linear" S-shaped relationship with the business performance of manufacturing enterprises in Ecuador.

\section{Methodology}

\subsection{Data}

The study was based on a secondary dataset of manufacturing businesses collected in Ecuador over 2003, 2007, 2010, and 2017 as part of the Enterprise Survey (ES) project annually by the World Bank (World Bank) targeting the top managers of the firms and their perceived awareness of the business environment. In the dataset, there are full 1,389 manufacturing firms. Only 90 enterprises were surveyed continuously in 4 years of 2003, 2006, 2010, and 2017. This also means a complete dataset of 90 firms is officially ready for regression analysis. The sample collection method is the stratified random sampling method, including the industrial sector, firm size, and regional stratification. First, industrial sector stratification includes the manufacturing industry (ISIC Revision.3.1 code 15-37), the retail sector (ISIC code 52), and other service industries (ISIC code 45, 50, 51, $60-64,72$ ). Second, firm size stratification is defined as a small business (from 5 to 19 employees), medium-sized enterprise (20 to 99 employees), and large-scale enterprise (100 employees or more). Third, regional stratification consists of three central Ecuadorian provinces: Pichincha, Guayas and Azuay.

\subsection{Model Specification}

To estimate the panel data model of the relationship between internationalization and business performance of enterprises in Ecuador, we apply a regression measurement method by calculating the Fixed Effects Model (FEM) and the Random Effects Model (REM) using STATA 14.0 econometric software. The procedures of estimation techniques are as follows. First, we conducted a hierarchical regression (adding control variables with DOI, $\mathrm{DOI}^{2}$, and $\mathrm{DOI}^{3}$, respectively) with the FEM and REM models. Second, we use the Hausman test to choose whether the FEM or REM model is the goodness of fit. The Hausman test results finally show the hypothesis $\mathrm{H}_{0}$ rejected at a significant level $1 \%$, meaning FEM model is chosen to explain the relationship between a dependent variable and independent variables. Besides, we tested multicollinearity and heteroskedasticity problems to guarantee the coefficient estimates' reliability (Gomes and Ramaswamy, 1999). VIF indicators are found to be smaller than 10, meaning that there are no multicollinearity phenomena (See table 1). Breusch and Pagan Lagrangian Multiplier Test result indicate existing heteroscedasticity $\left(\mathrm{H}_{0}\right.$ accepted at significant level $\left.>.10\right)$. To remedy this problem, we use a Robustness test of variance.

The econometric model is built with 11 independent variables selected, which characterizes DOI, firm characteristics, business environment traits derived from prior studies such as Contractor et al. (2003), Xiao et al. (2013), Wang et al. (2020) as follows:

$$
\begin{aligned}
& \operatorname{ROS}_{\mathrm{it}}=\beta_{0}+\beta_{1} \mathrm{DOI}^{3}{ }_{\mathrm{it}}+\beta_{2} \mathrm{DOI}^{2}{ }_{\mathrm{it}}+\beta_{3} \mathrm{DOI}_{\mathrm{it}}+\beta_{4} \text { FIRMSIZE }_{\mathrm{it}}+\beta_{5} \text { FIRMAGE }_{\mathrm{it}}+\beta_{6} \text { GENDER }_{\mathrm{it}}+\beta_{7} \text { TRAINING }_{\mathrm{it}} \\
& +\beta_{8} \text { COMP }_{\text {it }}+\beta_{9} \text { CUS }_{\text {it }}+\beta_{10} \text { BRI }_{\text {it }}+\beta_{11} \text { FINANCE }_{i t}+\beta_{12} \text { LABOR }_{i t}+\beta_{13} \text { BARRIERS }_{\text {it }}+\mathrm{u}_{\mathrm{it}}
\end{aligned}
$$

\subsection{Measurement of Variables}

\subsubsection{Dependent Variable}

Return on sales - ROS (Dependent variable): is measured by many different methods, depending on the research objectives of different authors. According to Bradley and O'Reagain (2001), enterprises' business performance is measured by export revenue. Beal (2000) re-determined that business performance should be measured by the growth of sales and profits growth in the previous year and the profit rate per total sales. Contractor et al. (2003) used the ratio of profit to net revenue ROS to measure enterprises' business performance. Following prior studies such as Hitt et al. (1994), Ramaswamy (1996), ROS was measured by the profit per net revenue ratio. 


\subsubsection{Independent Variables}

Degree of internationalization - DOI (Independent variable): There are many methods of measuring the level of internationalization of enterprises, Contractor et al. (2003) and Benito-Osorio et al. (2016) using indicators such as FSTS (foreign sales to total sales), FETE (foreign employees to entire staff) and FOTO (foreign offices to total offices) to measure the degree of internationalization of business when participating in the value chain global. Following prior studies, DOI was measured by FSTS as follows:

$$
F S T S=\frac{\text { foreign sales }}{\text { total sales }}
$$

Firm Size: In this study, firm size is measured by taking the natural logarithm of the total number of full-time employees of that enterprise (including management levels). According to Henderson and Fredrickson (1996), the scale is closely related to the enterprise's overseas expansion.

Firm Age: years of operation of the enterprise: measured by the number of years of business operation to the survey (2003, 2007, 2010, 2017). Yip et al. (2000) have demonstrated that the more long-term businesses are, the more bound the international market is and the resources to organize.

Gender: is a dummy variable, getting value one if manager gender is male, getting value 0 if manager gender is female. According to Felson and Gottfredson (1984), male managers are more likely than women to communicate and interact outside society.

Training: In this study, the control variable "The vocational training program for employees" is a dummy variable, receiving value one if the enterprise has organized a technical training program to improve their professional and professional qualifications and obtain a value of 0 if the enterprise does not have a skills training program.

The competition level - COMP: is measured on a 5-level Likert scale (from 0: no obstacles to 4: very severe obstacles). It can be said that competition is both an obstacle and a facilitating factor, especially in a business environment. The result of the competition is winning or losing or losing together winning together, or, therefore, it is creating specific difficulties for businesses, especially young companies in the field.

Customs and trade law - CUS: measured on a 5-level Likert scale (from 0: no obstacles to 4: very severe obstacles). When participating in internationalization, enterprises are doing business in the domestic market but are in an international scope or between the two countries.

Bribery- BRI: is a type of expense that accelerates the progress of a job or its stage, especially in business activities. Research measuring BRI variables by the formula:

$$
\mathrm{BRI}=\frac{\text { Total Bribery }}{\text { Total Revenue }} * 100
$$

Access to finance - FINANCE: is an important issue and concern for most businesses from small to large scale. Because most companies have many different capital sources and need to have plans for reasonable capital turnover, ensuring business activities are "seamless" and useful. It is measured on a 5-level Likert scale (from 0: no obstacles to 4: very severe obstacles)

Insufficient education of employees- LABOR (Inadequately educated workforce) Competence or qualification of the labor force has a severe impact on businesses' performance, including the service and manufacturing sectors. Accordingly, policymakers in the world today often emphasize the importance of strengthening the workforce capacity training to improve productivity. It is measured on a 5-level Likert scale (from 0: no obstacles to 4: Very severe obstacles).

Legal Barriers - BARRIERS: measured on a 5-level Likert scale (from 0: no obstacles to 4: very severe obstacles) and expected to have an opposite impact on the business performance. 


\section{Results and Discussions}

\subsection{Descriptive Statistics}

Table 1. Descriptive statistics of variables

\begin{tabular}{lllllll}
\hline Variables & Obs & VIF & Mean & Standard Deviation & Minimum & Maximum \\
\hline Return on Sales (ROS) & 360 & & 33.69 & 26.57 & -124.26 & 94.73 \\
\hline Degree of Internationalization (DOI) & 360 & 1.12 & 7.60 & 19.57 & 0 & 100 \\
\hline Firm size (FIRMSIZE) & 360 & 1.82 & 3.73 & 1.36 & 0,69 & 8.34 \\
\hline Firm age (FIRMAGE) & 360 & 1.41 & 26.65 & 21.61 & 2 & 128 \\
\hline Manager gender (GENDER) & 360 & 1.08 & 0.58 & 0.50 & 0 & 1 \\
\hline Training (TRAINING) & 360 & 1.37 & 0.71 & 13.31 & 0 & 1 \\
\hline Level of competition (COMP) & 360 & 1.22 & 1.93 & 7.95 & 0 & 4 \\
\hline Customs and trade laws (CUS) & 360 & 1.22 & 1.48 & 1.23 & 0 & 4 \\
\hline Bribery (BRI) & 360 & 1.03 & 0.63 & 1.20 & 0 & 4 \\
\hline Access to finance (FINANCE) & 360 & 1.19 & 1.50 & 1.35 & 0 & 4 \\
\hline $\begin{array}{l}\text { Insufficient education of employees } \\
\text { (LABOUR) }\end{array}$ & 360 & 1.28 & 1,71 & 0.46 & 0 & 4 \\
\hline Legal barriers (BARRIERS) & 360 & 1.19 & 2.65 & 9.10 & 0 \\
\hline SOurce: Wor & & & & 4 \\
\hline
\end{tabular}

Source: Worldbank Enterprises Survey $(2003,2006,2010,2017)$

Table 1 shows the variance inflation coefficient (VIF) of all variables is less than 10, as well as the correlation coefficient of the variables, is less than 0.800 (Table 2), this can be concluded that there is no multi-collinear phenomenon when considering all variables (including independent and control variables) into the research model. Therefore, it can be confirmed that the estimated results of the research model are not biased, statistically reliable. The number of observations is 360, including 90 Ecuadorian enterprises over 2003, 2006, 2010, and 2017. The average percentage of the business's profit-to-sales ratio is $33.69 \%$, with the lowest value is $-124.26 \%$, and the highest is $94.73 \%$. Meanwhile, the average internationalization level of Ecuadorian businesses is $7.60 \%$, which means that international sales accounted for $7.60 \%$ of the total sales. Not all enterprises participate in internationalization, having the lowest value of $0 \%$, which means they have not yet been involved in Internationalization. The highest is $100 \%$ when these enterprises export all of their goods and services to foreign markets.

Ecuador is one of the countries of the World Oil Export Organization. The oil exploration and export industry contributes more than a quarter of the country's GDP. However, to limit the economy's dependence and diversify economic sectors, Ecuador's orientation to develop into a regional trade center, the government has made policies to create the industry of non-oil in production - manufacturing. Therefore, there are still very few businesses participating in internationalization, expanding their foreign markets' business activities. Specifically, the degree of internationalization (DOI) of manufacturing enterprises in Ecuador is $7.601 \%$. However, in addition to businesses that solely produce and distribute products in the domestic market (93.520\% of the enterprises surveyed), meaning that the degree of internationalization of DOI is zero, there are still The company has entered the international market, or even, the products are produced entirely for export only; therefore, the degree of internationalization of DOI is equal to $100 \%$. Accordingly, the business performance of these businesses is also significantly affected. Specifically, the average business performance of enterprises is $33.686 \%$. Due to specific difficulties that companies have to face, especially for businesses that have not had experience in the international market, the costs incurred more than revenue result in a negative performance (-124.259\%). However, companies take advantage of the competitive advantage combining the potential of new markets, so the cost is optimal, positive business efficiency ROS (94.731\%). 
Table 2. Correlation matrix (bivariate Pearson)

\begin{tabular}{|c|c|c|c|c|c|c|c|c|c|c|c|c|c|c|}
\hline Variables & Mean & $\begin{array}{l}\text { Standard } \\
\text { Deviation }\end{array}$ & (1) & (2) & (3) & (4) & (5) & (6) & (7) & (8) & (9) & (10) & (11) & (12) \\
\hline (1)ROS & 33.69 & 26.57 & 1.000 & & & & & & & & & & & \\
\hline (2)DOI & 7.60 & 19.57 & $-0.051^{25}$ & 1.000 & & & & & & & & & & \\
\hline (3)FIRMSIZE & 3.73 & 1.36 & $0.023^{\operatorname{ms}}$ & $0.142^{*}$ & 1.000 & & & & & & & & & \\
\hline (4)FIRMAGE & 26.65 & 21.61 & $0.029^{\mathrm{ms}}$ & $0.024^{25}$ & $0.386^{*}$ & 1,000 & & & & & & & & \\
\hline (5)GENDER & 1.61 & 0.50 & $-0.062^{\mathrm{ms}}$ & $0.039^{\mathrm{as}}$ & $0.066^{* *}$ & $-0.091^{*}$ & 1.000 & & & & & & & \\
\hline (6)TRAINING & 1.32 & 13.31 & $-0.056^{\mathrm{ax}}$ & $-0.075^{* *}$ & $-0.329^{*}$ & $-0.081^{*}$ & $-0.050^{\mathrm{as}}$ & 1.000 & & & & & & \\
\hline (7)COMP & 1.93 & 7.95 & $-0.005^{\mathrm{as}}$ & $-0.170^{*}$ & $-0.083^{* *}$ & $0.019^{\mathrm{ms}}$ & $-0.082^{* *}$ & $0.052^{2 \mathrm{~s}}$ & 1,000 & & & & & \\
\hline (8)CUS & 1.48 & 1.23 & $0.002^{\mathrm{gs}}$ & $0.065^{* *}$ & $0.114^{*}$ & $0.001^{\mathrm{za}}$ & $0.001^{2 \mathrm{~s}}$ & $-0.144^{*}$ & $0.175^{*}$ & 1.000 & & & & \\
\hline (9)BRI & 0.63 & 1.20 & $-0.128^{*}$ & $-0.031^{\mathrm{ng}}$ & $-0.044^{\mathrm{mi}}$ & $-0.035^{m s}$ & $0.057^{* * *}$ & $0.050^{25}$ & $0.003^{\mathrm{nt}}$ & $0.005^{\mathrm{as}}$ & 1.000 & & & \\
\hline (10)FINANCE & 1.50 & 1.35 & $-0.005^{\mathrm{as}}$ & $0.043^{25}$ & $0.065^{* *}$ & $-0.063^{* *}$ & $-0.013^{\mathrm{ma}}$ & $0.027^{25}$ & $0.213^{*}$ & $0.238^{*}$ & $0.105^{*}$ & 1,000 & & \\
\hline (11)LABOR & 1.71 & 0.46 & $0.149 *$ & $-0.023^{\mathrm{ns}}$ & $0.023^{\mathrm{ns}}$ & $-0.024^{m s}$ & $-0.028^{\mathrm{ms}}$ & $-0.030^{\mathrm{ms}}$ & $0.235^{*}$ & $0.248^{*}$ & $-0.045^{\mathrm{ma}}$ & $0.225^{*}$ & 1,000 & \\
\hline (12)BARRIERS & 2.66 & 9.11 & $0.120^{*}$ & $0.058^{* * *}$ & $-0.003^{\mathrm{ma}}$ & $-0.002^{m s}$ & $0.056^{* * *}$ & $-0.024^{\mathrm{ma}}$ & $0.178^{*}$ & $0.223 *$ & $0.040^{\mathrm{ms}}$ & $0.221^{*}$ & $0.319 *$ & 1.000 \\
\hline
\end{tabular}

Note $(*)$ : Significant level at 1\%; (**): Significant level at 5\%; (***): Significant level at 10\%; (ns): non-significant

Table 2 presents the correlation matrix of variables, including the correlation coefficients between pairs of variables. Suppose the correlation coefficient between pairs of variables has a value of 0.6 or more. In that case, there is a strong correlation or robust notice that the problem of multicollinearity may occur. According to the correlation matrix, the correlation coefficient between the dependent variables is not a problem because the maximum correlation coefficient is only up to $31.9 \%$, meaning independent variables and control variables can be included in the model to explain the dependent variables, and it can be confirmed that no multi-collinear phenomena occur.

\subsection{Estimation Results}

The regression results for FEM and REM models presented in Table 3. The first three models regressed according to the FEM fixed-effects model. The 1st to 3rd exponent of the independent variable DOI is sequentially added from model 1 to model 3 to examine the impact of the independent variable internationalization level on firm performance and their non-linear system. In addition to the independent variable, ten other control variables are included permanently for all three models. Similarly, the REM random effects model is applied to model 5 to model 7.

Likewise, the independent variable (DOI) is multiplied by powers of 2 and 3 is introduced in turn from model 2 and model 3 in FEM and model 6 and model 7 in REM while we control other variables. To test the suitability level of the FEM or REM model, the study continues to perform the Hausman test. The Hausman test results show that the hypothesis $\mathrm{H}_{0}$ is rejected at the significance level of $1 \%(\mathrm{p}<0.01)$, suggesting that the FEM model is more suitable than REM in this study. Therefore, this model will be used to explain and test the research hypothesis.

Table 3. Regression results

\begin{tabular}{lllllll}
\hline \multirow{2}{*}{ Variables } & FEM & \multicolumn{5}{l}{ REM } \\
\cline { 2 - 7 } & Model 1 & Model 2 & Model 3 & Model 5 & Model 6 & Model 7 \\
\hline Constant & 113.938 & 115.323 & 119.805 & 38.740 & 37.650 & 38.573 \\
\hline Independent variables & & & & & & \\
\hline Degree of Internationalization & 0.294 & -0.644 & $3.675^{* *}$ & -0.065 & -0.370 & $-0.777^{* * *}$ \\
$($ DOI) & $(0.467)^{\text {std }}$ & $(1.868)$ & $(1.761)$ & $(0.048)$ & $(0.243)$ & $(0.459)$ \\
\hline \multirow{2}{*}{ DOI $^{2}$} & & 0.125 & $-0.164^{* *}$ & & 0.004 & 0.019 \\
& & $(0.025)$ & $(0.065)$ & & $(0.003)$ & $(0.014)$ \\
\hline DOI $^{3}$ & & & $0.002^{* *}$ & & & -0.000 \\
& & & $(0.001)$ & & & $(0.000)$ \\
\hline
\end{tabular}




\begin{tabular}{|c|c|c|c|c|c|c|}
\hline \multicolumn{7}{|c|}{ Control Variables } \\
\hline \multirow{2}{*}{ FIRMSIZE } & -8.613 & -7.638 & -6.341 & $2.777 * *$ & $3.154 * *$ & $3.010 * *$ \\
\hline & $(12.759)$ & $(13.205)$ & $(12.795)$ & $(1.241)$ & (1.299) & (1.318) \\
\hline \multirow[t]{2}{*}{ FIRMAGE } & 0.962 & 0.982 & $1.599 * *$ & 0.095 & 0.099 & 0.096 \\
\hline & $(0.603)$ & $(0.833)$ & $(0.738)$ & $(0.075)$ & $(0.074)$ & $(0.073)$ \\
\hline \multirow{2}{*}{ GENDER } & -5.862 & -6.391 & -9.712 & -4.277 & -4.295 & -4.117 \\
\hline & $(8.750)$ & $(8.540)$ & (9.084) & (2.963) & (2.938) & $(2.961)$ \\
\hline \multirow{2}{*}{ TRAINING } & -0.914 & -2.793 & -1.686 & -2.128 & -1.668 & -1.924 \\
\hline & (12.641) & (12.018) & (11.096) & (3.414) & (3.499) & (3.488) \\
\hline \multirow{2}{*}{ COMP } & 2.323 & 2.241 & 5.464 & 0.764 & 0.739 & 0.745 \\
\hline & $(5.871)$ & $(5.737)$ & (5.218) & $(1.250)$ & $(1.245)$ & (1.248) \\
\hline \multirow{2}{*}{ CUS } & -2.857 & -3.493 & -3.333 & -0.033 & 0.102 & 0.173 \\
\hline & $(4.019)$ & $(3.569)$ & (3.645) & (1.000) & (1.008) & (1.015) \\
\hline \multirow{2}{*}{ BRI } & $-7.382 *$ & $-6.755^{* *}$ & $-7.570^{*}$ & $0.573^{*}$ & $0.554^{*}$ & $0.551 *$ \\
\hline & (2.786) & $(2.857)$ & (2.474) & $(0.171)$ & $(0.170)$ & $(0.171)$ \\
\hline \multirow{2}{*}{ FINANCE } & -6.077 & -5.148 & $-7.488 * * *$ & -2.148 & -2.236 & -2.246 \\
\hline & (4.224) & $(4.459)$ & (4.024) & (1.416) & (1.427) & (1.429) \\
\hline \multirow{2}{*}{ LABOR } & -5.652 & -4.919 & $-6.773 * * *$ & -1.859 & -1.917 & -1.909 \\
\hline & $(4.112)$ & (4.144) & (3.815) & (1.414) & (1.407) & (1.409) \\
\hline \multirow[t]{2}{*}{ BARRIERS } & -3.842 & -3.463 & -3.697 & 0.731 & 0.711 & 0.648 \\
\hline & $(2.890)$ & (2.703) & $(2.731)$ & $(0.941)$ & $(0.941)$ & $(0.950)$ \\
\hline $\mathrm{N}$ & 360 & 360 & 360 & 360 & 360 & 360 \\
\hline $\mathrm{R}^{2}$ & $29.210 \%$ & $30.430 \%$ & $42.360 \%$ & $0.200 \%$ & $0.200 \%$ & $0.260 \%$ \\
\hline P-value & 0.000 & 0.000 & 0.000 & 0.000 & 0.000 & 0.000 \\
\hline
\end{tabular}

Note: $(*)$ : Significant level at 1\%; (**): Significant level at 5\%; (**): Significant level at 10\%; Values in parentheses: standard errors

Model 3 in the FEM model is chosen to explain the relationship between DOI and firm performance (ROS). Accordingly, in this model, the DOI variable affects the dependent variable ROS in the form of an inverted S (with $\mathrm{R}^{2}$ $=42,360 \%$; $p<0.01$ ), meaning that the variety of firm performance can be explained by $42,360 \%$ from estimated predictors and other control variables. The results show an existing inverted S-shaped between the degree of internationalization and firm performance and are statistically significant at the $5 \%$ level $(\mathrm{p}<0.05)$. Namely, the estimated coefficients of DOI1, DOI2, and DOI3 are $(\beta=3.675),(\beta=-0.164)$, and $(\beta=0.002)$ respectively.

\subsection{Discussions}

We suggest that the relationship between DOI and performance exhibits an inverted S-shaped form that is high at lower and higher DOI but low at medium DOI.

Stage 1: The positive slope - early internationalizer does improve performance

In the first stage, the empirical finding supports the positive impact of the degree of internationalization (DOI) on a firm's performance $(\beta=3.675 ; \mathrm{p}<0.05$ ). Unlike Contractor et al. (2003)'s result, our contradicting result shows that internationalization strategy for manufacturing firms may significantly improve their performance at the early stage of international expansion. Ruigrok and Wagner (2003) suggest that firms are likely to exploit economies of scale and scope when they initially consider foreign activities a source of quick profits, thereby achieving higher performance. Also, market or resource-seeking manufacturing firms, as is often viewed as a firm with a large scale of production or perhaps owned by (a) foreign/multinational companies operating in a culturally heterogeneous market, 
may reap the benefits of economies of scale and economies of scope. This is because culturally unrelated international diversification may induce new and diverse ideas or opportunities from heterogeneous markets. As a result, firms in culturally different environments can generate, combine, and transfer intangible assets or tacit knowledge within operating units to achieve the most valuable internationalization benefits (Ruigrok and Wagner, 2003).

Stage 2: The negative slope - the adverse effects of further international expansion

After achieving initial benefits derived from economies of scale and scope in heterogeneous markets and thus exceeding the maximum threshold of business performance in the first phase, the benefits of further international expansion decrease as DOI continuously increases $(\beta=-0.164 ; \mathrm{p}<0.05)$. The incremental costs of further global expansion are now greater than the incremental benefits. For example, due to culturally unrelated diversification, firms may find it challenging to deal with the complexity of an increasing imbalance between external environments and internal competencies. This induces misalignment problems that require firms reconfigure their internal structures and organizational systems to be suitable for a new market environment.

Stage 3: Positive slope - Back to the competitive advantage edge

In the third phase, firms finally learned from the local environment (Salomon and Shaver, 2005) how to enhance their FSAs used in production, engineering, marketing processes, and management (Collinson and Rugman, 2008) overcome LOF in the region. Therefore, a high degree of internationalization (greater than $38.936 \%$ ) will have a positive impact $(\beta=0.002 ; \mathrm{p}<0.05)$.

In last-stage international expansion, further international expansion or high DOI contributes gradually with positive returns to firm performance $(\beta=0.002 ; \mathrm{p}<0.050)$. Hence, multi-market diversification may reduce fixed costs and overhead costs that are spread over more nations (Lu and Beamish, 2004). Under geographical diversification circumstances, through direct or indirect export activities, firms via external business networks can meet "undesirable" requirements from foreign customers, identify new opportunities abroad or overseas sales (Leonidou et al., 2007). The problems of the liability of newness and foreignness would not be the case for the established firms because they finally learned from the local environment (Salomon and Shaver, 2005) how to enhance their firm-specific advantages used in production, engineering, and marketing processes and management (Lu and Beamish, 2004; Collinson and Rugman, 2008). At this point, a well-developed product standardization strategy, known as to extend the product cycle, can help save costs as the liability of foreignness costs decreases after firms accumulate knowledge in the overseas business environment, firm-specific advantages management, and marketing, as well as economies of scale (Hutchinson et al., 2007). Moreover, most established manufacturing firms operating in emerging economies may be wholly-or-partly owned by foreign companies, which is often known as the increased export volume because of intra-industry trade phenomena.

Control variables. Although firm size is not statistically significant with firm performance, the number of years of operation positively impacts performance $(\beta=1.599 ; \mathrm{p}<0.05)$. More than $90 \%$ of manufacturing firms in Ecuador are small and medium-sized, with an average "age" of about 27 years. Bribery cost hurts the business performance $(\beta=$ $-7.570, \mathrm{p}<0.01)$. Similarly, financial accessibility harms manufacturing enterprises' business performance in Ecuador $(\beta=-7.488 ; p<0.10)$. Hence, access to finance is challenging. In other words, insufficient employee education harms firm performance $(\beta=-6.773 ; \mathrm{p}<0.10)$. The higher the obstacle level of employee qualification due to inadequate education (on the Likert scale, level 4 is extremely obstructive), the lower the business's performance.

\section{Conclusions}

Our study concludes the non-linear relationship between DOI and firm performance at different internationalization phases under the inverted S-shape given a dataset. Interestingly, it contradicts the findings of Contractor et al. (2003) and Lu and Beamish (2004). Specifically, at low and high international expansion levels, DOI was positively associated with firm performance, while lower performance exists at medium internationalization levels. We proposed a contradictory interpretation of both empirical and theoretical perspectives different from the previous empirical studies and the current literature. Hence, the DOI-performance link's interpretation varies depending on the industrial contexts and particular country (Xiao et al., 2013). Different from other researchers emphasizing services firms, our targeted firms are in the manufacturing sector. In addition to the current literature, we tested our theory using firm-level panel data (both cross-sectional and longitudinal data) from 90 manufacturing firms over 2003, 2006, 2010, and 2017 in Ecuador.

Moreover, we shed new light on manufacturing firms' growth by addressing different business environment barriers in emerging economies. This study implies that market or product diversification strategy can help firms benefit from internationalization faster. However, firms should attempt to achieve a quick learning process, reconfigure internal 
management systems, and formulate a suitable international strategy in compliance with culturally external global business, thereby obtaining better performance.

This study goes without some limitations. First, our data were limited to only manufacturing firms in Ecuador. Other services firms in emerging economies may be included to compare the difference between the DOI-performance relationships. Our contradictory findings may be limited to generalize the exact shape for this relationship. Therefore, to improve the results' generalizability, future research might be conducted with panel data at different sectors and countries, especially for emerging economies. Second, macro-environmental risks or barriers that may play a moderating role in the DOI-performance relationship are needed to consider in future research models.

\section{References}

Assaf, A. G., Josiassen, A., \& Ratchford, B. T. (2012). Internationalization and performance of retail firms: a Bayesian dynamic model. Journal of Retailing, 88(2), 191-205. https://doi.org/10.1016/j.jretai.2011.11.005

Beal, R. M. (2000). Competing effectively: environmental scanning, competitive strategy, and organization performance in small manufacturing firms. Journal of Small Business Management, 38(1), 27-47.

Benito-Osorio, D., Colino, A., Guerras-Martín, L. Á., \& \& Zúñiga-Vicente, J. Á. (2016). The international diversification-performance link in Spain: Does firm size really matter?. International Business Review, 25(2), 548-558. https://doi.org/10.1016/j.ibusrev.2015.09.004

Bradley, F., \& O' Reagain, S. (2001). Deriving international competitive advantage in SMEs through product market and business system resource allocation. Irish Journal of Management, 22(2), 19-44.

Collinson, S., \& Rugman, A. M. (2008). The regional nature of Japanese Multinational business. Journal of International Business Studies, 39(2), 215-230. https://doi.org/10.1057/palgrave.jibs.8400347

Contractor, F. J., Kumar, V., \& Kundu, S. K. (2007). Nature of the relationship between international expansion and performance: The case of emerging market firms. Journal of World Business, 42(4), 401-417. https://doi.org/10.1016/j.jwb.2007.06.003

Contractor, F. J., Kundu, S. K., \& Hsu, C. C. (2003). A three-stage theory of international expansion: the link between multinationality and performance in the service sector. Journal of International Business Studies, (34), 5-19. https://doi.org/10.1057/palgrave.jibs. 8400003

Felson, M., \& Gottfredson, M. (1984). Social Indicators of Adolescent activities near peers and parents. Journal of Marriage and Family, 43(6), 709. https://doi.org/10.2307/352612

Gankema, H. G. J., Snuif, H. R., \& Zwart, P. S. (2000). The Internationalization Process of Small and Medium Sized Enterprises: An Evaluation of Stage Theory. Journal of Small Business Management, 38(4), 15-27.

Gomes, L., \& Ramaswamy, K. (1999). An empirical examination of the form of the relationship between multinationality and performance. Journal of International Business Studies, 30(1), 173-187. https://doi.org/10.1057/palgrave.jibs.8490065

Henderson, A. D., \& Fredrickson, J. W. (1996). Information-processing demand as a determinant of CEO compensation. The Academy of Management Journal, 39(3), 575-606. https://doi.org/10.2307/256656

Hitt, M. A., Hoskisson, R. E., \& Ireland, R. D. (1994). A mid-range theory of the interactive effects of international and product diversification on innovation and performance. Journal of Management, 20(2), 297-326. https://doi.org/10.1177/014920639402000203

Hutchinson, K., Nicholas, A., Quinn, B., \& Doherty, A. M. (2007). Internationalization motives and facilitating factors: qualitative evidence from smaller specialist retailers. Journal of International Marketing, 15(3), 96-122. https://doi.org/10.1509/jimk.15.3.96

Johanson, J., \& Vahlne, J. E. (1977). The internationalization process of the firm-A model of knowledge development and increasing foreign market commitments. Journal of International Business Studies, 8(1), 23-32. https://doi.org/10.1057/palgrave.jibs.8490676

Kumar, V., \& Singh, N. (2008). Internationalization and performance of Indian pharmaceutical firms. Thunderbird International Business Review, 50(5), 321-330. https://doi.org/10.1002/tie.20217

Leonidou, L. (1995). Export barriers: non-exporters' perceptions. International Marketing Review, 12(1), 4-25. https://doi.org/10.1108/02651339510080070

Leonidou, L., Katsikeas, C. S., Palihawadana, D., \& Spyropoulou, S. (2007). An analytical review of the factors stimulating smaller firms to export. International Marketing Review, 24(6), 735-770. https://doi.org/10.1108/02651330710832685 
Lu, J. W., \& Beamish, P. W. (2001). The internationalization and performance of SMEs. Strategic Management Journal, 22, 565-586. https://doi.org/10.1002/smj.184

Lu, J. W., \& Beamish, P. W. (2004). International diversification and firm performance: The S-curve hypothesis. Academy of Management Journal, 47(4), 598-609. https://doi.org/10.2307/20159604

Luo, X., \& Zheng, Q. (2018). How firm internationalization is recognized by outsiders: The response of financial analysts. Journal of Business Research, 90, 87-106. https://doi.org/10.1016/j.jbusres.2018.04.030

McDougall, P. P., \& Oviatt, B. M. (2000). International entrepreneurship: the intersection of two research paths. Academy of Management Journal, 43(5), 902-906. https://doi.org/10.2307/1556418

Michel, A., \& Shaked, I. (1986). Multinational corporations vs. domestic corporations: Financial performance and characteristics. Journal of International Business Studies, 17(3), 89-100. https://doi.org/10.1057/palgrave.jibs.8490435

Pangarkar, N. (2008). Internationalization and performance of small-and medium-sized enterprises. Journal of World Business, 43(4), 475-485. https://doi.org/10.1016/j.jwb.2007.11.009

Peng, M. W., Sun, S. L., Pinkham, B., \& Chen, H. (2009). The institution-based view as a third leg for a strategy tripod. Academy of Management Perspectives, 23(3), 63-81. https://doi.org/10.5465/amp.2009.43479264

Ramaswamy, K., Kroeck, K. G., \& Renforth, W. (1996). Measuring the degree of internationalization of a firm: A comment. Journal of International Business $\quad$ Studies, 27(1), 167-177. https://doi.org/10.1057/palgrave.jibs.8490131

Ruigrok, W., \& Wagner, H. (2003). Internationalization and performance: An organizational learning perspective. MIR: Management International Review, 63-83.

Ruigrok, W., Amann, W., \& Wagner, H. (2007). The internationalization - Performance relationship at Swiss Firms: A test of the S-Shaped and Extreme Degrees of Internationalization. Management International Review, 47(3), 349-368. https://doi.org/10.1007/s11575-007-0020-6

Salomon, R. M., \& Shaver, M. (2005). Learning by Exporting: New insights from Examining firm innovation. Journal of Economics and Management Strategy, 14(2), 431-460. https://doi.org/10.1111/j.1530-9134.2005.00047.x

Wang, C. F., Chen, L. Y., \& Chang, S. C. (2011). International diversification and the market value of new product introduction. Journal of International Management, $17(4), \quad 333-347$. https://doi.org/10.1016/j.intman.2011.03.002

Wang, G., Zhang, H., Xia, B., Wu, G., \& Han, Y. (2020). Relationship between Internationalization and Financial performance: evidence from ENR-Listed Chinese firms. Journal of Management in Engineering, 36(2), 04019044. https://doi.org/10.1061/(ASCE)ME.1943-5479.0000736

Xiao, S. S., Jeong, I., Moon, J. J., Chung, C. C., \& Chung, J. (2013). Internationalization and performance of firms in China: Moderating effects of governance structure and the degree of centralized control. Journal of International Management, 19(2), 118-137. https://doi.org/10.1016/j.intman.2012.12.003

Yip, G., Biscarri, J. G., \& Monti, J. A. (2000). The role of the internationalization process in the performance of newly internationalizing firms. Journal of International Marketing, 8(3), 10-35. https://doi.org/10.1509/jimk.8.3.10.19635

Zaheer, S., \& Mosakowski, E. (1997). The dynamics of the liability of Foreigness: A global study of survival in financial services. Strategic Management Journal, $18(6), \quad 439-464$. https://doi.org/10.1002/(SICI)1097-0266(199706)18:6<439::AID-SMJ884>3.0.CO;2-Y

Zahra, S. A., Ireland, R. D., \& Hitt, M. A. (2000). International expansion by new venture firms: International diversity, mode of market entry, technological learning, and performance. Academy of Management Journal, 43(5), 925-950. https://doi.org/10.5465/1556420

\section{Copyrights}

Copyright for this article is retained by the author(s), with first publication rights granted to the journal.

This is an open-access article distributed under the terms and conditions of the Creative Commons Attribution license (http://creativecommons.org/licenses/by/4.0/). 